\title{
Correction to: A Review of Aflibercept Treatment for Macular Disease
}

Rodrigo Anguita $\cdot$ Anastasia Tasiopoulou $\cdot$ Syed Shahid $\cdot$

Janice Roth · Sing Yue Sim · Praveen J. Patel

Published online: July 2, 2021

(C) The Author(s) 2021

\section{Correction to: Ophthalmol Ther https://doi.org/10.1007/s40123-021- 00354-1}

The following text was missing from the Acknowledgements section of the original article.

\section{Acknowledgements}

During the peer review process, the manufacturer of the agent under review was offered an opportunity to comment on the article. Changes resulting from comments received were made by the author based on their scientific and editorial merit.

The original article has been corrected.
The original article can be found online at https://doi. org/10.1007/s40123-021-00354-1.

R. Anguita $\cdot$ A. Tasiopoulou $\cdot$ S. Shahid $\cdot$ J. Roth .

S. Y. Sim · P. J. Patel ( $\square)$

National Institute of Health Research Biomedical Research Centre at Moorfields Eye Hospital and UCL Institute of Ophthalmology, London, UK e-mail: praveen.patel1@nhs.net

A. Tasiopoulou

Royal Devon and Exeter Hospital, Exeter, UK

\section{OPEN ACCESS}

This article is licensed under a Creative Commons Attribution-NonCommercial 4.0 International License, which permits any noncommercial use, sharing, adaptation, distribution and reproduction in any medium or format, as long as you give appropriate credit to the original author(s) and the source, provide a link to the Creative Commons licence, and indicate if changes were made. The images or other third party material in this article are included in the article's Creative Commons licence, unless indicated otherwise in a credit line to the material. If material is not included in the article's Creative Commons licence and your intended use is not permitted by statutory regulation or exceeds the permitted use, you will need to obtain permission directly from the copyright holder. To view a copy of this licence, visit http://creativecommons.org/licenses/by$\mathrm{nc} / 4.0 /$. 